\title{
A bal kamrai globális longitudinális strain károsodott szisztémás szklerózisban és korrelál a betegek funkcionális kapacitásával
}

\author{
Vértes Vivien'1, Nógrádi Ágnes', Porpáczy Adél', Minier Tünde², \\ Czirják László , Komócsi András', Faludi Réka'
}

Pécsi Tudományegyetem, Klinikai Központ, ${ }^{1}$ Szívgyógyászati Klinika, ${ }^{2}$ Reumatológiai és Immunológiai Klinika, Pécs

Levelezési cím:

Dr. Faludi Réka, 7624 Pécs, Ifjúság u. 13. E-mail: faludi.reka@pte.hu

\begin{abstract}
Bevezetés: Szisztémás szklerózisban (SSc) a szívizom szubklinikus érintettsége gyakori, és jelentősen rontja e betegek életkilátásait. A 2D-speckle tracking alapú globális longitudinális strain (GLS) új paraméter, ami alkalmas a balkamra-funkció korai, szubklinikus károsodásának kimutatására is. Munkánk célja annak vizsgálata volt, hogy a bal kamrai GLS-értékek mutatnak-e összefüggést a klinikai és echokardiográfiás adatokkal, valamint a betegek funkcionális állapotával és életminőségével SSc-ben.

Betegek, módszerek: 72 SSc-s beteget vizsgáltunk (életkoruk 58,6士10,1 év, 66 nő). Eredményeiket 23 főnyi, nemben és életkorban illesztett egészséges önkéntes adataival hasonlítottuk össze. Kizárási kritériumokként határoztuk meg a pulmonalis artériás hipertóniát, pitvarfibrillációt, a csökkent bal kamrai ejekciós frakciót $(<55 \%)$ valamint a szignifikáns bal oldali billentyűbetegséget. A rutin echokardiográfiás mérések mellett digitális felvételek is készültek, amelyekből meghatároztuk a GLS-t. Az életminőség vizsgálatára SF-36 kérdőívet használtunk. A paraméterek közötti összefüggések vizsgálatára parciális korrelációt használtunk, az életkor szerepelt korrigáló tényezőként.

Eredmények: A SSc-s betegekben szignifikánsan alacsonyabb GLS-értéket találtunk az egészségesekkel összehasonlítva $(-17,2 \pm 2,3$ vs. $-18,7 \pm 1,4 \%, p=0,001)$. A GLS-érték szignifikáns pozitív korrelációt mutatott az SSc fennállásának idejével a Raynaud-tünet $(r=0,274 ; p=0,021)$, és a non-Raynaud tünetek megjelenésétöl $(r=0,245 ; p=0,039)$ valamint a betegek New York Heart Association funkcionális osztályával $(r=0,242 ; p=0,042)$, míg negatív korrelációt az SF-36 kérdőív fizikális komponensével $(r=-0,250 ; p=0,040)$.

Következtetés: A 2D-speckle tracking alapú GLS alkalmas a balkamra-funkció korai, szubklinikus károsodásának kimutatására SSc-ben. A GLS összefüggést mutat a betegség fennállásának idejével, valamint szignifikáns meghatározója a betegek funkcionális kapacitásának és életminőségének ebben a kórképben.
\end{abstract}

Kulcsszavak: globális longitudinális strain, szisztémás szklerózis, szisztolés diszfunkció, funkcionális kapacitás

Left ventricular global longitudinal strain is impaired in systemic sclerosis and shows a significant correlation with the functional capacity of the patients

Introduction: The subclinical myocardial involvement is common in systemic sclerosis (SSc) and is associated with poor prognosis. 2D-speckle-tracking-derived global longitudinal strain (GLS) is a reliable tool to detect the subclinical impairment of the left ventricular (LV) function. Our aim was to investigate if LV GLS shows any correlation with the clinical and echocardiographic data as well as with the functional status and quality of life of the patients in SSc.

Patients, methods: 72 SSc patients (58.6 \pm 10.1 years, 66 female) were investigated. Their results were compared with the data of 23 gender- and age-matching healthy volunteers. Exclusion criteria were: pulmonary arterial hypertension, atrial fibrillation, reduced LV ejection fraction $(<55 \%)$ or significant left sided valvular disease. In addition to the standard echocardiography, loops were stored digitally for the off-line analysis of the GLS. SF-36 questionnaire was used to assess quality of life. Partial correlation analysis was used to investigate the correlations between the parameters, with age as corrective factor. Results: In SSc patients significantly lower GLS values were found compared to healthy persons $(-17.2 \pm 2.3$ vs. $-18.7 \pm 1.4 \%$, $p=0.001)$. Durations of the disease from the onset of the Raynaud phenomenon $(r=0.274 ; p=0.021)$ and from the first non-Raynaud symptoms $(r=0.245 ; p=0.039)$ show significant correlation with $G L S$. In addition, GLS values showed significant correlation with the New York Heart Association functional class of the patients $(r=0.242 ; p=0.042)$ and with physical functioning component of the SF-36 survey ( $r=-0.250 ; p=0.040)$.

Conclusion: 2D-speckle-tracking-derived GLS is a suitable tool to detect the early, subclinical LV dysfunction in patients with SSc. GLS shows correlation with the duration of the disease, and is a significant determinant of the functional capacity and quality of life of the patients in SSc.

Keywords: global longitudinal strain, systemic sclerosis, systolic dysfunction, functional capacity 


\section{Bevezetés}

A szisztémás szklerózis (SSc) a bőr és a belső szervek kóros fibrózisához vezető, több szervrendszerben is tüneteket okozó autoimmun betegség ismeretlen etiológiával. Epidemiológiai adatok szerint a kardiális érintettség gyakori SSc-ben és $20-30 \%$-ban felelős a korai halálozásért (1-3). A fibrózis elsősorban a bal kamra diasztolés funkcióját károsítja, amihez a szöveti Doppler-mérések tanúsága szerint a szisztolés funkció szubklinikus károsodása társul (4-7), míg az ejekciós frakció általában megtartott SSc-ben (3).

A 2D-speckle tracking alapú globális longitudinális strain (GLS) új echokardiográfiás paraméter, ami az irodalmi adatok alapján alkalmas a szisztolés balkamra-funkció korai, szubklinikus károsodásának kimutatására is. Más kórképekben, többek között veleszületett aortasztenózisban és hipertrófiás cardiomyopathiában szenvedő betegeknél korrelációt mutatott a szívizomfibrózis jelenlétével, és a szívelégtelen betegek funkcionális kapacitásával is, megtartott és károsodott ejekciós frakciójú populációban egyaránt (8-11). Munkánk célja annak vizsgálata volt, hogy egészséges populációval összehasonlítva a bal kamrai GLS-értékek alkalmasak-e az alapbetegség bal kamrai manifesztációjának igazolására SSc-ben. Vizsgáltuk még, hogy a GLS-értékek mutatnak-e összefüggést az echokardiográfiás és klinikai adatokkal, valamint a betegek funkcionális állapotával és életminőségével ebben a kórképben.

\section{Betegek és módszerek}

\section{Betegpopuláció}

Prospektív vizsgálatunkba 80 beteget vontunk be, akiket a Pécsi Tudományegyetem Klinikai Központ Reumatológiai és Immunológiai Klinikán gondoznak SSc diagnózissal. A vizsgálatból kizártuk azokat a betegeket, akiknél pulmonalis artériás hipertónia, pitvarfibrilláció, ismert koszorúér-betegség vagy szignifikáns bal oldali billentyübetegség állt fent, valamint akiknek csökkent volt a bal kamrai ejekciós frakciója $(<55 \%)$. Vizsgáltuk a betegek részletes anamnézisét és gyógyszerszedési szokásait. A betegség fennállásának idejét az első Raynaud-, illetve nem-Raynaud-tünet megjelenésétöl az echokardiográfiás vizsgálat időpontjáig eltelt időként definiáltuk, években. Eredményeiket egy nemben és korban illesztett egészséges önkéntes csoport eredményeivel hasonlítottuk össze.

Vizsgálatunkat a Pécsi Tudományegyetem Klinikai Központ Regionális Tudományos és Kutatásetikai Bizottságától kapott engedély alapján, a beteg által aláírt beleegyező nyilatkozat birtokában végeztük, miután részletes tájékoztatást adtunk a vizsgálatról.

\section{Echokardiográfia}

Az echokardiográfiás vizsgálatokhoz Philips EPIQ 7 készüléket (Philips Healthcare, Best, Hollandia) használ- tunk. Biplane Simpson-módszerrel határoztuk meg a bal kamrai ejekciós frakciót. A bal kamrai izomtömeget a Devereux-formula segítségével számoltuk ki, majd testfelszínre normalizáltuk. Color Doppler-technikával vizsgáltuk a mitralis regurgitáció mértékét, amit az ajánlások alapján osztályoztunk (12). A jobb kamrai szisztolés nyomást a tricuspidalis regurgitáció sebességéből számoltuk ki a módosított Bernoulli-képlet alapján. A jobb pitvari nyomást a vena cava inferior tágassága és összenyomhatósága alapján becsültük (5-10-15 Hgmm) (13). Pulzatilis Doppler használatával határoztuk meg a mitralis beáramlási görbe paramétereit, majd kiszámoltuk az E/A arányt. Szöveti Dopplerrel a mitralis anulus septalis és lateralis régiójában határoztuk meg az S, e' és a' hullám maximális sebességét. A septalis és lateralis anuluson nyert eredményeket átlagoltuk, majd átlagos E/e' arányt számoltunk. A Doppler-paraméterek esetében három egymást követő görbén végzett mérés eredményét átlagoltuk. A bal kamra diasztolés funkcióját az aktuális ajánlás alapján értékeltük (14).

Speckle tracking echokardiográfiával határoztuk meg a bal kamrai GLS-t. Ehhez digitális felvételeket készítettünk csúcsi négyüregi-, kétüregi- és hosszmetszeti nézetben. A felvételek EKG-monitorozás mellett történtek, légzésszünetben. Minimum három szívciklust magába foglaló felvételeket rögzítettünk. Ezután egy speciális szoftver (Qlab 10.5, Philips Healthcare, Andover, Massachusetts, Egyesült Államok) segítségével offline elemeztük a felvételeket. A módszer kivitelezhetőségével és reprodukálhatóságával kapcsolatos eredmények korábban már leírásra kerültek (15).

\section{Funkcionális állapot és életminőség}

A betegek funkcionális állapotát a New York Heart Association stádiumuk alapján osztályoztuk, amit a betegek panaszai alapján határoztunk meg.

A betegek kitöltötték az életminőség vizsgálatára validált Short Form, azaz SF-36 kérdőívet, amely segítségével felmértük fizikális és érzelmi állapotukat (16).

\section{Statisztikai módszerek}

A kategorikus változókat gyakoriság és százalék formájában fejeztük ki, a folytonos változókhoz pedig átlagot \pm szórást számoltunk. A csoportok közötti különbség szignifikanciájának vizsgálatához kétmintás t-próbát, míg a kategorikus változók esetében khi négyzet próbát használtunk. A GLS és az echokardiográfiás paraméterek közötti korrelációt Pearson-módszerrel vizsgáltuk. A GLS és a vizsgált egyéb változók közötti korreláció elemzését parciális korrelációs analízissel végeztük, az életkort használva korrekciós faktorként (életkorra normalizált korrelációs vizsgálat), illetve „partial regression plot"-ok formájában grafikusan is ábrázoltuk az összefüggéseket. Vizsgálataink során a $p<0,05$ értéket fogadtuk el szignifikánsnak. Adataink feldolgozását IBM SPSS 22 (IBM SPSS Inc., Chicago, Illinois, USA) szoftverrel végeztük. 


\section{Eredmények}

A 80 betegböl 72 beteget tudtunk bevonni a vizsgálatba. 8 beteget kizártunk nem megfelelő akusztikus ablak (4 beteg) vagy bal kamrai „foreshortening” (a felvételen nem a valódi balkamra-csúcs ábrázolódik) miatt (4 beteg). A betegek részletes klinikai adatait az 1. és 2. táblázat mutatja be. A betegek között 66 nő és 6 férfi volt. Az átlagos életkoruk 58,6 $\pm 10,1$ év. Közel egyenlő volt a két különböző scleroderma altípusban (IcSSc-ben [n=35] és dcSSc-ben [n=37]) szenvedő betegek száma.

Az egészséges csoportba 21 nőt és 2 férfit vontunk be, átlagos életkoruk 56,0 $\pm 6,7$ év. Az egészséges kontrollcsoport korban, nemi arányaiban és a testfelszínüket figyelembe véve is megegyezett az SSc-s betegcsoporttal. A 72 beteg echokardiográfiás jellemzöit a kontrollcsoporttal összehasonlítva a 2. táblázat mutatja be. Az ejekciós frakció szignifikánsabban magasabb volt a kontrollcsoportban, de a betegcsoportban mért értékek is megtartottak (>55\%) voltak, így a különbség klinikailag nem tekinthető jelentősnek. Ugyanakkor az SSc-betegekben szignifikánsan alacsonyabb GLS-értéket határoztunk meg az egészségesekéhez képest. Szignifikánsan alacsonyabb mitralis e' értékeket mér-

1. TÁBLÁZAT. A szisztémás szklerózisos betegcsoport klinikai jellemzői

\section{Klinikai változók}

\section{Érték}

SSc fennállásának ideje (év)

Raynaud-tünet megjelenésétől

$13,6 \pm 10,7$

Nem-Raynaud tünet megjelenésétöl

$7,7 \pm 5,9$

Limitált kután SSc $\mathrm{n}(\%)$

$35(49)$

Hipertónia n (\%)

$36(51)$

Angiotenzin konvertáz enzim gátló $\mathrm{n}(\%)$

$36(50)$

Kálciumcsatorna-blokkoló $n(\%)$

$36(50)$

$35(49)$

Kacsdiuretikum n (\%)

$18(25)$

Mineralokortikoid-receptor blokkoló n (\%)

New York Heart

$$
\text { I n (\%) }
$$

Association

I - II n (\%)

stádium

$$
\begin{aligned}
& \text { II n (\%) } \\
& \text { II - III n (\%) } \\
& \text { III n (\%) }
\end{aligned}
$$

Vörösvérsejt-süllyedés $(\mathrm{mm} / \mathrm{h})$

$21,4 \pm 15,5$

C-reaktív protein $(\mathrm{mg} / \mathrm{l})$

$3,4 \pm 4,2$

Kreatinin $(\mu \mathrm{mol} / \mathrm{l})$

$70,5 \pm 23,0$

NT-proBNP (pg/ml)

$185,0 \pm 156,4$

Erőltetett kilégzési vitálkapacitás (FVC) (\%)

$100,8 \pm 16,4$

Szénmonoxid-diffúziós kapacitás (DLCO) (\%)

$64,2 \pm 15,0$

SF-36 föbb

Fizikális komponens (\%)

$39,4 \pm 10,6$

komponensei

Mentális komponens (\%)

$67,1 \pm 23,6$

Általános egészség (\%)
2. TÁBLÁZAT. A szisztémás szklerózisos betegcsoport

\begin{tabular}{|c|c|c|c|c|}
\hline \multicolumn{2}{|c|}{ Változók } & $\begin{array}{c}\text { Sziszté- } \\
\text { más } \\
\text { szkleró- } \\
\text { zis (n=72) }\end{array}$ & $\begin{array}{l}\text { Egész- } \\
\text { séges } \\
\text { kontroll- } \\
\text { csoport } \\
(n=23)\end{array}$ & $\mathbf{p}$ \\
\hline \multicolumn{2}{|c|}{ Életkor (év) } & $58,6 \pm 10,1$ & $56,0 \pm 6,7$ & 0,957 \\
\hline \multicolumn{2}{|c|}{ Testfelszín (m²) } & $1,8 \pm 0,2$ & $1,8 \pm 0,2$ & 0,523 \\
\hline \multicolumn{2}{|c|}{ Nö n (\%) } & $66(92)$ & 21(91) & 0,957 \\
\hline \multicolumn{2}{|c|}{$\begin{array}{l}\text { Bal kamrai ejekciós } \\
\text { frakció }(\%)\end{array}$} & $60,8 \pm 4,6$ & $63,5 \pm 2,4$ & 0,010 \\
\hline \multicolumn{2}{|c|}{ GLS (\%) } & $-17,2 \pm 2,3$ & $-18,7 \pm 1,4$ & 0,001 \\
\hline \multicolumn{2}{|c|}{ Átlagos mitralis S (cm/s) } & $8,3 \pm 1,3$ & $9,9 \pm 1,4$ & $<0,001$ \\
\hline \multicolumn{2}{|c|}{ Átlagos mitralis e' (cm/s) } & $8,1 \pm 1,9$ & $11,1 \pm 1,5$ & $<0,001$ \\
\hline \multicolumn{2}{|c|}{ Átlagos mitralis a' (cm/s) } & $9,9 \pm 1,6$ & $10,0 \pm 1,3$ & 0,881 \\
\hline \multicolumn{2}{|c|}{ Mitralis E/A } & $1,1 \pm 0,3$ & $1,4 \pm 0,3$ & $<0,001$ \\
\hline \multicolumn{2}{|c|}{ Átlagos E/e' } & $9,5 \pm 3,0$ & $7,2 \pm 1,3$ & $<0,001$ \\
\hline \multicolumn{2}{|c|}{$\begin{array}{l}\text { Bal kamrai izomtömeg/ } \\
\text { testfelszín }\left(\mathrm{g} / \mathrm{m}^{2}\right)\end{array}$} & $97,0 \pm 19,5$ & $83,4 \pm 11,6$ & $<0,001$ \\
\hline \multirow{3}{*}{$\begin{array}{l}\text { Bal } \\
\text { kamrai } \\
\text { diasz- } \\
\text { tolés } \\
\text { funkció }\end{array}$} & $\begin{array}{l}\text { Normális n } \\
(\%)\end{array}$ & $24(33)$ & $23(100)$ & \multirow{3}{*}{$<0,001$} \\
\hline & $\begin{array}{l}\text { Károsodott } \\
\text { relaxáció n } \\
(\%)\end{array}$ & $23(32)$ & 0 & \\
\hline & $\begin{array}{l}\text { Pszeudonor- } \\
\text { mális n (\%) }\end{array}$ & $25(35)$ & 0 & \\
\hline \multirow{3}{*}{$\begin{array}{l}\text { Mitrális } \\
\text { regur- } \\
\text { gitáció } \\
\text { foka }\end{array}$} & Enyhe n (\%) & $66(92)$ & $22(96)$ & \multirow{3}{*}{0,136} \\
\hline & Közepes n (\%) & $6(8)$ & $1(4)$ & \\
\hline & Súlyos n (\%) & 0 & 0 & \\
\hline
\end{tabular}
echokardiográfiás adatai az egészséges kontrollcsoporttal összehasonlítva

A szignifikáns $(p<0,05)$ értékeket bold betütípussal jelöltük.

tünk, és szignifikánsan magasabb átlagos bal kamrai E/e'-t határoztunk meg a betegekben, a kontrollcsoporthoz képest. A bal kamrai diasztolés funkció csak a betegek 33\%-ában volt megtartott, ám a diasztolés funkciózavar legsúlyosabb (restriktív) formája egy betegnél sem volt jelen. Ezzel szemben az egészséges populációban mindenkinél normális diasztolés funkció volt észlelhető. A bal kamrai izomtömeg szignifikánsan magasabb volt az SSc-s csoportban. A mitralis regurgitáció jellemzően enyhe volt mindkét populációban.

Az echokardiográfiás paraméterek közül a GLS szignifikáns korrelációt mutatott az átlagos mitralis e' értékkel $(r=-0,285 ; p=0,019)$, ám az átlagos E/e' értékkel nem $(r=0,082 ; p=0,511)$.

Parciális korrelációs analízis alapján, ahol az életkort használtuk korrekciós faktorként, a GLS szignifikáns, pozitív korrelációt mutatott a Raynaud-tünet megjelenésétöl (1. ábra) és a non-Raynaud tünetek megjelenésétől eltelt idővel egyaránt, valamint a betegek NYHA stádiumával (2. ábra), míg negatív korrelációt az SF-36 kérdőív fizikális komponensével (3. táblázat). 


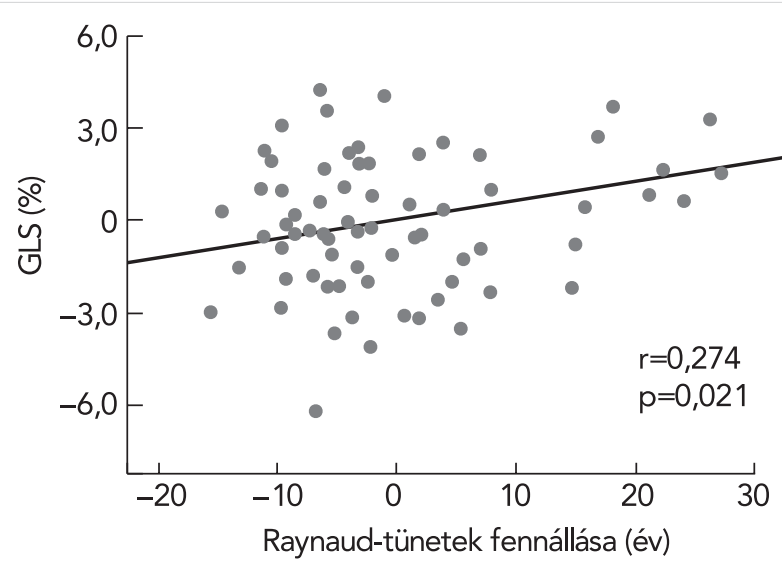

1. ÁBRA. Parciális regressziós egyenes: a GLS korrelál a betegség fennállásának idejével (az ábrán a Raynaud-tünet megjelenésétől), életkorra történő normalizálást követően is

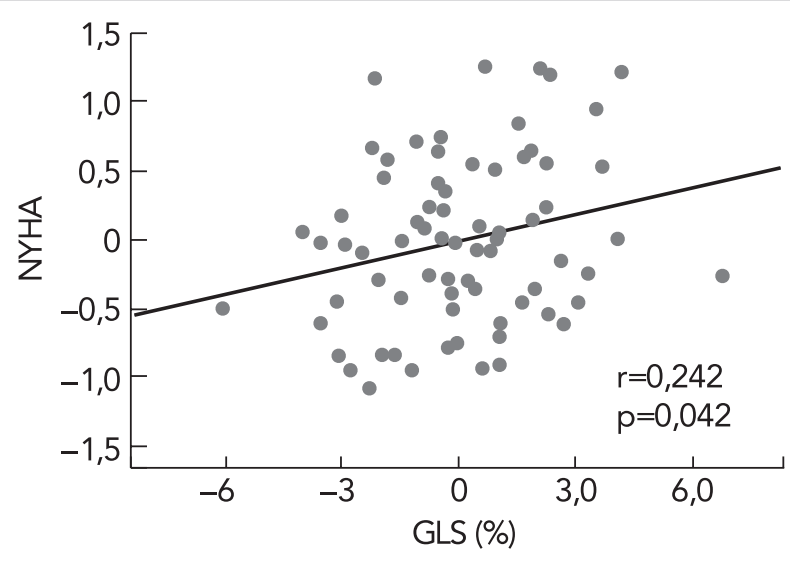

2. ÁBRA. Parciális regressziós egyenes: a GLS a betegek funkcionális állapotának meghatározója, életkorra történő normalizálást követően is

3. TÁBLÁZAT. Parciális korrelációs analízis a GLS és az egyéb változók között

\begin{tabular}{|l|r|c|}
\hline SSc fennállásának ideje (év) & r & p \\
\hline Raynaud-tünet megjelenésétől & & \\
\hline Nem Raynaud tünetek megjelenésétöl & 0,274 & $\mathbf{0 , 0 2 1}$ \\
\hline SF-36 fizikális komponense & $-0,250$ & $\mathbf{0 , 0 3 9}$ \\
\hline NYHA stádium & 0,039 \\
\hline
\end{tabular}

A szignifikáns $(p<0,05)$ értékeket bold betütípussal jelöltük

\section{Megbeszélés}

A bal kamrai diasztolés funkciózavarhoz gyakran társul a szisztolés funkció korai, szubklinikus károsodása (14). A 2D-speckle tracking alapú GLS kiválóan alkalmas ennek kimutatására. Az irodalmi adatok alapján a GLS lényegesen alkalmasabb a kardiovaszkuláris események és a halálozás előjelzésére, mint a bal kamrai ejekciós frakció (17). A GLS prediktora a kardiovaszkuláris kimenetelnek megtartott ejekciós frakcióval járó szívelégtelen (HFpEF) populációban, függetlenül az egyéb klinikai tényezőktől és a rutin echokardiográfiás mérések eredményeitől (18). Ng és munkatársai a bal kamrai GLS-t vizsgálták különböző súlyosságú aortasztenózisban szenvedő betegeknél. Eredményeik alapján a károsodott GLS a mortalitás prediktora ebben a populációban függetlenül az aortasztenózis súlyosságától vagy az ejekciós frakciótól (19).

A miokardiális érintettség gyakori SSc-ben, és rosszabb prognózist jelent. A kórképre jellemző fibrózis elsősorban a bal kamra diasztolés funkcióját károsítja (5), míg az ejekciós frakció általában megtartott SSc-ben (3). Az általunk vizsgált betegcsoportban is megtartott volt az ejekciós frakció, ugyanakkor a 2D-speckle tracking echokardiográfia segítségével mért GLS szignifikánsan alacsonyabb volt az SSc betegcsoportban az egészségesekhez képest. Az irodalomkutatás során egyetlen munkacsoport eredményei voltak fellelhetők, akik szintén 2D-speckle tracking alapú GLS használatával vizsgáltak egy 22 főből álló SSc-populációt, és szignifikánsan károsodott GLS-értékeket találtak az egészséges kontrollcsoporthoz képest $(20,21)$. Jelen tanulmányunkban egy nagyobb létszámú betegpopuláció vizsgálatával megerősítettük ezeket az eredményeket. Az egészséges kontrollpopulációban mért GLS-értékeink jó megegyezést mutatnak az azonos szoftver felhasználásával mért referenciaértékekkel (13). Feltételezhető tehát, hogy a GLS alkalmas a kórképre jellemző szívizom-fibrózis kimutatására. Szív MR-eredmények alapján sclerodermás betegekben a szívizom fibrózisa általában diffúz jellegü, ami az extracelluláris tér volumenével jól jellemezhető. Összefüggést mutattak ki a szív MR-rel mért extracelluláris volumenfrakció és a bal kamrai diasztolés funkció károsodása között sclerodermás betegekben (22). Bár sclerodermában még nem vizsgálták ezt a kérdést, egyéb kórképekben, például veleszületett aortasztenózis vagy hipertrófiás cardiomyopathia esetében már igazolták azt is, hogy a bal kamrai strain korrelál a szív MR-vizsgálattal igazolt fibrózis mértékével $(8,11)$. Diabéteszben is igazolták ezt a tényt, állatkísérletes eredmények segítségével (23). Ennek fényében természetes, hogy a betegség fennállásának időtartama is jelentősen befolyásolja a GLS-t, mivel a korábbi eredmények szerint a szívizom-fibrózis súlyossága korrelál a betegség fennállásának idejével SSc-ben (5).

Hasselberg és munkatársai a betegek funkcionális kapacitását vizsgálták HFpEF-populációban, és eredményeik alapján a 2D-speckle tracking echokardiográfia alapú GLS alkalmas a csökkent terhelhetőségű betegek azonosítására (9). Krishnasamy és munkatársai hasonló eredményre jutottak krónikus vesebetegek vizsgálata során: a GLS korrelációt mutatott a betegek funkcionális kapacitása mellett az életminőségével is (10). Eredményeink tehát egybevágnak a korábbi tanul- 
mányok eredményeivel. Biering-Sørensen és munkatársainak munkája magyarázattal is szolgálhat a jelenségre. Igazolták ugyanis, hogy a nyugalomban mért bal kamrai GLS egyértelmű korrelációt mutat a terhelésre jelentkező töltőnyomás-emelkedés mértékével megtartott ejekciós frakcióval bíró populációban (24). Ez szoros összefüggést feltételez a szisztolés balkamra-funkció szubklinikus károsodása és a bal kamrai relaxáció között, ami demonstrálható volt az általunk vizsgált populációban is.

\section{Következtetések}

\section{A 2D-speckle tracking alapú GLS alkalmas a balkam- ra-funkció korai, szubklinikus károsodásának kimutatá- sára SSc-ban. A GLS összefüggést mutat a betegség fennállásának idejével, valamint szignifikáns meghatá- rozója a betegek funkcionális kapacitásának és életmi- nőségének ebben a kórképben.}

\section{Irodalom}

1. Komócsi A, Vorobcsuk A, Faludi R,et al. The impact of cardiopulmonary manifestations on the mortality of SSc: a systematic review and meta-analysis of observational studies. Rheumatology 2012; 51 1027-36. doi: 10.1093/rheumatology/ker357

2. Champion HC. The Heart in Scleroderma. Rheum Dis Clin North Am 2008; 34: 181-90. doi: 10.1016/j.rdc.2007.12.002

3. Allanore $\mathrm{Y}$, Meune $\mathrm{C}$, Vonk MC, et al. Prevalence and factors associated with left ventricular dysfunction in the EULAR Scleroderma Trial and Research Group (EUSTAR) database of patients with systemic sclerosis. Ann Rheum Dis 2010; 69: 218-21. doi: 10.1136/ ard.2008.103382

4. Hinchcliff M, Desai CS, Varga J, et al. Prevalence, prognosis, and factors associated with left ventricular diastolic dysfunction in systemic sclerosis. Clin Exp Rheumatol 2012; 30: S30-7.

5. Faludi R, Költő Gy, Bartos B, et al. Five-year follow-up of left ventricular diastolic function in systemic sclerosis patients: determinants of mortality and disease progression. Semin Arthritis Rheum 2014; 44: 220-7. doi: 10.1016/j.semarthrit.2014.04.001

6. Armstrong GP, Whalley GA, Doughty RN, et al. Left ventricular function in scleroderma. Br J Rheumatol 1996; 35: 983-988.

7. Valetini G, Vitale DF, Giunta A et al. Diastolic abnormalities is systemic sclerosis: evidence for associated defective reserve. Ann Rheum Dis 1996; 55: 455-460.

8. Dusenbery SM, Lunze FI, Jerosch-Herold M, et al. Left ventricular strain and myocardial fibrosis in congenital aortic stenosis. Am J Cardiol 2015; 116: 1257-1262. doi: 10.1016/j.amjcard.2015.07.042 9. Hasselberg NE, Haugaa KH, Sarvari SI et al. Left ventricular global longitudinal strain is associated with exercise capacity in failing hearts with preserved and reduced ejection fraction. Eur Heart J Cardiovasc Imaging 2015; 16: 217-224. doi: 10.1093/ehjci/jeu277 10. Krishnasamy R, Hawley CM, Stanton T, et al. Association between left ventricular global longitudinal strain, health-related quality of life and functional capacity in chronic kidney disease patients with preserved ejection fraction. Nephrology 2016; 21: 108-15. doi: 10.1111/nep.12557

11. Popović ZB, Kwon DH, Mishra M, et al. Association between regional ventricular function and myocardial fibrosis in hypertrophic car- diomyopathy assessed by speckle tracking echocardiography and delayed hyperenhancement magnetic resonance imaging. J Am Soc Echocardiogr 2008; 21: 1299-305. doi: 10.1016/j.echo.2008.09.011 12. Zoghbi WA, Adams D, Bonow RO, et al. Recommendations for noninvasive evaluation of native valvular regurgitation. A report from the American Society of Echocardiography. Developed in collaboration with the Society for Cardiovascular Magnetic Resonance. J Am Soc Echocardiogr 2017; 30: 303-371. doi: 10.1016/j. echo.2017.01.007

13. Lang RM, Badano LP, Mor-Avi V, et al. Recommendations for cardiac chamber quantification by echocardiography in adults: an update from the American Society of Echocardiography and the European Association of Cardiovascular Imaging. Eur Heart J Cardiovasc Imaging 2015; 16: 233-70. doi: 10.1093/ehjci/jev014

14. Nagueh SF, Smiseth OA, Appleton CP et al. Recommendations for the evaluation of left ventricular diastolic function by echocardiography: an update from the American Society of Echocardiography and the European Association of Cardiovascular Imaging. J Am Soc Echocardiogr 2016; 29: 277-314. doi: 10.1016/j.echo.2016.01.011 15. Wisotzkey BL, Jorgensen NW, Albers EL, et al. Feasibility and interpretation of global longitudina strain imaging in pediatric heart transplant recipients. Pediatr Transplant 2017; 21: e12909. doi: 10.1111/petr.12909

16. Ware JE, Sherbourne CD. The MOS 36-item short-form health survey (SF-36). I. Conceptual framework and item selection. Med Care 1992; 30: 473-483.

17. Kalam K, Otahal P, Marwick TH. Prognostic implications of global LV dysfunction: a systematic review and meta-analysis of global longitudinal strain and ejection fraction. Heart 2014; 100: 1673-1680. doi: 10.1136/heartjnl-2014-305538

18. Huang W, Chai SV, Lee SGS, et al. Prognostic factors after index hospitalization for heart failure with preserved ejection fraction. J Am Coll Cardiol 2017; 119: 2017-2020. doi: 10.1016/j.amjcard.2017.03.032

19. Ng ACT, Prihadi EA, Antoni ML, et al. Left ventricular global longitudinal strain is predictive of all-cause mortality independent of aortic stenosis severity and ejection fraction. Eur Heart J Cardiovasc Imaging 2018; 19: 859-867. doi: 10.1093/ehjci/jex189

20. Spethmann S, Dreger H, Schattke S, et al. Two-dimensional speckle tracking of the left ventricle in patients with systemic sclerosis for an early detection of myocardial involvement. Eur Heart J Cardiovasc Imaging 2012; 13: 863-870. doi: 10.1093/ehjci/jes047 21. Spethmann S, Rieper K, Riemekasten G, et al. Echocardiographic follow-up of patients with systemic sclerosis by $2 \mathrm{D}$ speckle tracking echocardiography of the left ventricle. J Cardiovasc Ultrasound 2014; 12: 13. doi: 10.1186/1476-7120-12-13.

22. Thuny F, Lovric D, Schnell F, et al. Quantification of myocardial extracellular volume fraction with cardiac MR imaging for early detection of left ventricle involvement in systemic sclerosis. Radiology 2014; 274: 373-380. doi: 10.1148/radiol.13131280

23. Mátyás $C$, Kovács $A$, Németh $B T$, et al. Comparison of speckle-tracking echocardiography with invasive hemodynamics for the detection of characteristic cardiac dysfunction in type-1 and type-2 diabetic rat models. Cardiovasc Diabetol 2018; 17: 13. doi: 10.1186/ s12933-017-0645-0

24. Biering-Sørensen $T$, Santos $M$, Rivero J, et al. Left ventricular deformation at rest predicts exercise-induced elevation in pulmonary artery wedge pressure in patients with unexplained dyspnoea. Eur J Heart Fail 2017; 19: 101-110. doi: 10.1002/ejhf.659 